\title{
Enhanced Secretion of Escherichia coli $\beta$-Lactamase by a Spontaneous Erythromycin-resistant Mutant of Bacillus subtilis
}

\author{
By YOICHI NAGAMI ${ }^{1 *}$ AND TERUO TANAKA ${ }^{2}$ \\ ${ }^{1}$ Research Center of Mitsubishi Kasei Corporation, 1000 Kamoshida, Midori-ku, Yokohama-shi, \\ Kanagawa 227, Japan \\ ${ }^{2}$ Mitsubishi-Kasei Institute of Life Sciences, 11 Minamiooya, Machida-shi, Tokyo 194, Japan
}

(Received 5 July 1988; revised 14 November 1988; accepted 8 December 1988)

\begin{abstract}
An extracellular-protease-deficient mutant, ME142, was isolated from Bacillus subtilis as a spontaneous erythromycin-resistant $\left(E^{r}{ }^{r}\right)$ clone. This mutant showed conditional sporulation and only sporulated normally in the absence of erythromycin. In the presence of the antibiotic, sporulation was greatly reduced. Production of extracellular proteases by ME 142 also exhibited conditional deficiency, possibly due to pleiotropic effects of the sporulation deficiency. The production of protease was $2-10 \%$ that of the wild-type level in the presence of erythromycin. ME142 showed poor competence for transformation even in the absence of erythromycin; however, derivatives of ME142 were isolated which had the same Eryr phenotype but which exhibited normal competence. One such mutant, ME162, was used as a host for the secretion of Escherichia coli $\beta$-lactamase. The amount of $\beta$-lactamase in the culture supernatants of ME162 increased significantly when the cells were cultured with erythromycin, suggesting that proteolysis of the $\beta$-lactamase in the supernatants of ME162 was greatly reduced as compared to that in the supernatants of the wild-type strain.
\end{abstract}

\section{INTRODUCTION}

Among mutants of Bacillus subtilis showing resistance to several antibiotics are some that have been shown to be asporogeneous (Piggot \& Coote, 1976). Some erythromycin-resistant $($ Eryr) mutants for example, show conditional sporulation, exhibiting a temperature-sensitive sporulation (Spo ${ }^{\text {ts }}$ ) phenotype or sporulating only in the absence of erythromycin (Sharrock $e t$ al., 1981). An Ery ${ }^{\mathrm{r}} \mathrm{Spo}^{\text {ts }}$ strain obtained by mutagenesis with ethyl methane sulphonate failed to sporulate at a high temperature $\left(47^{\circ} \mathrm{C}\right)$ irrespective of the presence of erythromycin, but sporulated normally at $30-35^{\circ} \mathrm{C}$ (Goldman \& Tipper, 1979). Domoto et al. (1975) reported a spontaneous Eryr mutant (ery1040) which grew normally in the presence or absence of erythromycin but sporulated only in its absence. The fact that erythromycin affects the $50 \mathrm{~S}$ ribosomal subunit and that Ery ${ }^{\mathrm{r}}$ mutants have an altered ribosomal protein $\mathrm{L}-17$ suggests a possible involvement of translation in the regulation of sporulation (Sharrock et al., 1981).

Recent advances in the ability to manipulate genes in B. subtilis, and its capacity to secrete large amounts of protein into the growth medium, have led to this organism being used as a host for the synthesis and secretion of foreign proteins. A number of groups have reported the construction of secretion vector systems utilizing genes for Bacillus extracellular enzymes such as $\alpha$-amylase, penicillinase and protease (Chang et al., 1983; Palva et al., 1983; Honjo et al., 1985; Shiroza et al., 1985). However, in all cases, the yields of foreign gene products recovered from the culture medium were less than $10 \%$ of the original enzyme level. The main reason for the reduction in productivity seems to be degradation by the extracellular alkaline and neutral proteases (Shiroza et al., 1985; Ulmanen et al., 1985). Accordingly, extracellular-proteasedeficient mutants have been isolated to overcome this problem. Recently, some investigators have reported success in secreting foreign proteins by use of protease-deficient mutants carrying 
lesions in the structural genes of proteases (Nakamura et al., 1985; Wong et al., 1986; Fahnestock \& Fischer, 1987; Honjo et al., 1987) or by using a spo0A mutant (Fahnestock \& Fischer, 1986).

In this paper, we describe the isolation of a spontaneously occurring Eryr mutant which sporulates only in the absence of erythromycin. Since this mutant produces less than $10 \%$ of the extracellular protease activity of the wild-type strain in the presence of erythromycin, we have used it to examine the production and stability of Escherichia coli $\beta$-lactamase. We discuss the potential value of this mutant as a host for the production of foreign proteins in $B$. subtilis.

\section{METHODS}

Bacterial strains and plasmids. Bacterial strains used in this study are listed in Table 1. Plasmids pNYB3, for the extracellular production of $\beta$-lactamase, and $\mathrm{pNZ2}$, for the intracellular production of $\beta$-galactosidase, are shown in Fig. $1(a, b)$. Plasmid pNYB3 was constructed as follows. A synthetic oligonucleotide (Fig. $1 c$ ), containing both a ribosome-binding site and the signal peptide coding region of the Bacillus amyloliquefaciens $\alpha$-amylase gene (Palva et al., 1982) was fused in-frame to the $E$. coli $\beta$-lactamase structural gene (bla) lacking the signal sequence (Palva et al., 1982). This fused fragment was introduced into the EcoRI and HindIII sites of the $B$. subtilis vector pNC601 (Kamakura et al., 1987). Plasmids pNZ2 and pUB110 were described previously (Nagami \& Tanaka, 1986; McKenzie et al., 1986).

Media. The media used in this study were $2 \times$ SG medium (Leighton \& Doi, 1971), LB agar, and minimal agar consisting of Spizizen's minimal medium (Spizizen, 1958) supplemented with Casamino acids $(0.5 \%)$, tryptophan $\left(50 \mu \mathrm{g} \mathrm{ml}^{-1}\right)$ and agar $(1.5 \%, \mathrm{w} / \mathrm{v})$. Trimethoprim, erythromycin and kanamycin were added to a final concentration of 1,2 and $5 \mu \mathrm{g} \mathrm{ml}^{-1}$, respectively, unless otherwise stated.

Growth and sporulation. Cells were cultured in $2 \times \mathrm{SG}$ medium at $37^{\circ} \mathrm{C}$ for $24 \mathrm{~h}$ with shaking. Heat-resistant spores and viable cells were counted by plating on to LB agar plates with or without heat treatment at $80^{\circ} \mathrm{C}$ for $10 \mathrm{~min}$. Growth was monitored in a Klett-Summerson colorimeter equipped with a no. 66 red filter.

Transformation. Transformation of $B$. subtilis competent cells with plasmid DNA was performed as described previously (Tanaka \& Kawano, 1980). Transformants were selected on Spizizen agar plates containing either kanamycin (for pUB110) or trimethoprim (for pNC601).

Enzyme assay. Activities of protease in the culture supernatants, $\beta$-galactosidase in the cell extracts and $\beta$-lactamase in both supernatants and extracts were assayed as described previously (Nagami \& Tanaka, 1986; Tanaka et al., 1987).

\section{RESULTS}

\section{Isolation and characterization of Ery ${ }^{r}$ mutants}

Spontaneous Ery ${ }^{r}$ mutants of $B$. subtilis MT142 were selected on Spizizen agar plates containing erythromycin $\left(2 \mu \mathrm{g} \mathrm{ml}^{-1}\right)$ at $37^{\circ} \mathrm{C}$. The frequency of mutation was about $4.3 \times 10^{-8}$ per colony-forming unit. One of these mutants was designated as ME142 and used for further study. The ability of ME142 to sporulate was reduced only slightly in the absence of erythromycin, but was greatly reduced in its presence (Table 2). All of the resulting heatresistant spores of ME142 obtained in the absence of erythromycin exhibited erythromycin resistance, indicating that they were not revertants. These results demonstrate that ME142 belongs to the ery 1040 type of conditional asporogeneous mutant reported by Domoto et al. (1975). In the absence of erythromycin, the growth pattern of ME142 was similar to that of MT142. In the presence of erythromycin, however, ME142 grew at the same rate as MT142 until the early stationary phase, but the final cell density of ME142 was slightly less than that of MT142.

Since the appearance of extracellular proteases is closely associated with the process of sporulation (Piggot \& Coote, 1976), we examined the activity of extracellular proteases in ME142 (Table 3). When ME142 was grown with erythromycin, the protease activities in the culture supernatants during the stationary phase $(12,24,48 \mathrm{~h})$ were only $2-10 \%$ of those found for MT142. In the absence of erythromycin however, the protease activities of MT142 and ME142 were comparable. The protease level of the neutral-protease-deficient mutant MT-2 (Fujii et al., 1983) at $12 \mathrm{~h}$ was similar to that found for ME142 in the presence of erythromycin, but increased about 5-20-fold with increasing culture time $(24,48 \mathrm{~h})$, possibly due to the production of alkaline protease. These results suggest that ME142 could be a more effective protease-deficient mutant than MT-2. Furthermore, these results clearly show that extracellular production of proteases is closely associated with sporulation. 
(a)

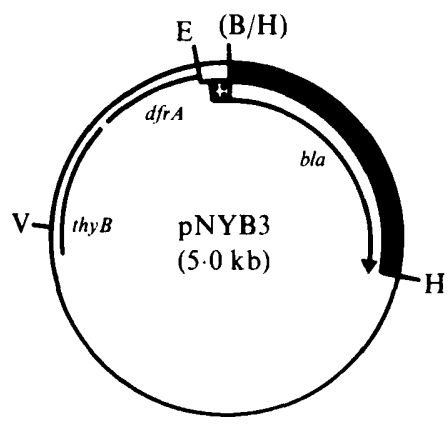

(b)

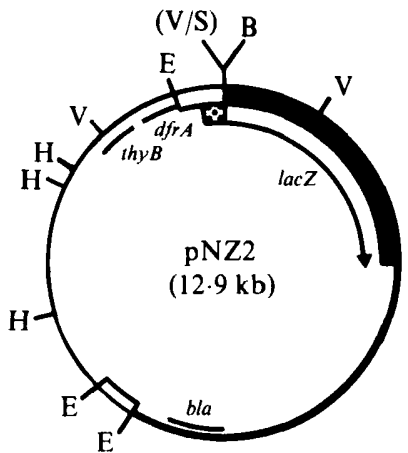

(c)

$$
\begin{aligned}
& \text { EcoRI } \quad B g I I I \quad \rightarrow B \text {. amyloliquefaciens } \alpha \text {-amylase signal sequence }
\end{aligned}
$$

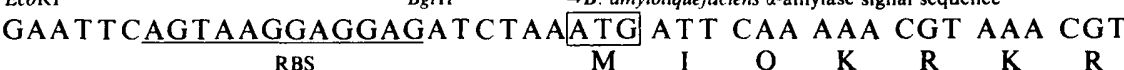

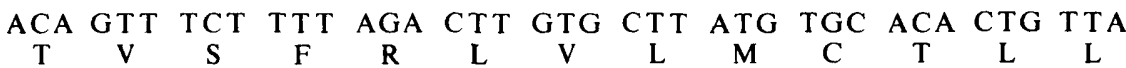

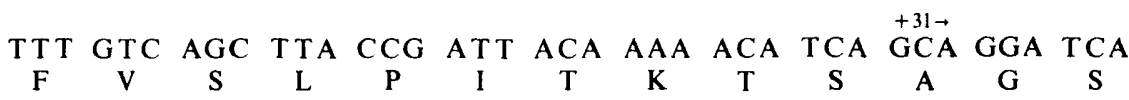

$$
\begin{aligned}
& \begin{array}{ccccc}
\text { junction region } \rightarrow \text { bla } & & & \\
\text { GCT } & \text { TGC } & \text { CCC } & \text { CCA } & \text { GGA } \\
\text { A } & \text { C } & \text { P } & P & \text { G }
\end{array}
\end{aligned}
$$

Fig. 1. Physical maps of the expression plasmids pNYB3 and pNZ2. The letters in parentheses indicate the recognition sites which were cleaved with the respective enzymes, filled in and blunt-end ligated. bla, dfr $A$, lac $Z$ and thy $B$ designate the $E$. coli $\beta$-lactamase (ampicillin resistance), $B$. subtilis Tmp ${ }^{\top}$-dihydrofolate reductase, $E$. coli $\beta$-galactosidase and $B$. subtilis thymidylate synthase B genes, respectively. (a) pNYB3. The filled box shows the bla gene that lacks its own signal sequence. The open box indicates the synthetic oligonucleotide ( $117 \mathrm{bp}$ ) whose nucleotide sequence is shown in $(c)$. The ribosome-binding site (RBS) and the $B$. amyloliquefaciens $\alpha$-amylase signal sequence are shown by the dotted region. The thin line represents the vectof region of $\mathrm{pNC601}$. The internal arrow shows the direction of translation. (b) pNZ2. The filled box shows the lacZ gene lacking the first eight codons of the amino-terminal end. The open box indicates the prt $R$ gene (Nagami \& Tanaka, 1986), whose open reading frame (amino acids $1-26$ ) is shown by the dotted region. The thin and thick lines represent the vector regions of pNC6 (Nagami \& Tanaka, 1986) and pBR322, respectively. The internal arrow indicates the direction of translation. $(c)$ The nucleotide sequence of the synthetic oligonucleotide in pNYB3. The deduced amino acid sequence (one-letter symbols) is also shown. The underline indicates the RBS. Abbreviations: B, BamHI; E, EcoRI; H, HindIII; S, SmaI; V, EcoRV.

Table 1. Bacillus subtilis strains used in this study

\begin{tabular}{|c|c|c|}
\hline Strain & Properties* & Origin or reference \\
\hline MT142 & arg-15 leuB8 trpE thyA; Tmp ${ }^{\mathrm{r}}$ & This study \\
\hline ME142 & arg-15 leuB8 trpE thyA; Tmp ${ }^{r}$ Ery & This study \\
\hline ME152 & arg-15 leuB8 thyA; Tmpr Eryr & This study (MI112 DNA $\rightarrow$ ME142) \\
\hline ME162 & arg-15 leuB8; Ery & This study (ME152 DNA $\rightarrow$ RM125) \\
\hline 11112 & arg-15 leuB8; thr5 recE4 hsmM hsrM & Tanaka \& Kawano (1980) \\
\hline M125 & arg-15 leuB8 hsmM hsrM & Uozumi et al. (1977) \\
\hline MT-2 & leuC7 trpC2 hsmM hsrM; $\mathrm{Npr}^{-}$ & Fujii et al. (1983) \\
\hline
\end{tabular}

* Tmp ${ }^{r}$, trimethoprim resistance; Eryr, erythromycin resistance; $\mathrm{Npr}^{-}$, deficiency of extracellular neutral protease. 
Table 2. Sporulation frequency of MT142 and Ery ${ }^{r}$ mutants

$\begin{array}{ccccc}\text { Strain } & \begin{array}{c}\text { Addition of } \\ \text { erythromycin }\end{array} & \begin{array}{c}\text { No. of } \\ \text { viable cells ml } l^{-1}\end{array} & \begin{array}{c}\text { No. of } \\ \text { spores ml } l^{-1 *}\end{array} & \begin{array}{c}\text { Sporulation } \\ \text { frequency (\%) }\end{array} \\ \text { MT142 } & - & 8.6 \times 10^{8} & 5.0 \times 10^{8} & 58 \\ \text { ME142 } & - & 3.5 \times 10^{8} & 1.1 \times 10^{8} & 32 \\ \text { ME142 } & + & 5.3 \times 10^{8} & 3.9 \times 10^{5} & 0.072 \\ \text { ME152 } & - & 6.5 \times 10^{8} & 5.6 \times 10^{8} & 86 \\ \text { ME152 } & + & 2.7 \times 10^{8} & 6.4 \times 10^{4} & 0.023 \\ \text { ME162 } & - & 4.3 \times 10^{8} & 2.6 \times 10^{8} & 61 \\ \text { ME162 } & + & 1.7 \times 10^{8} & 9.1 \times 10^{4} & 0.053\end{array}$

* Sporulation was examined after $24 \mathrm{~h}$ incubation with or without erythromycin $\left(2 \mu \mathrm{g} \mathrm{ml}^{-1}\right)$ as described in Methods.

Table 3. Production of extracellular proteases by MT142 and Eryr mutants

\begin{tabular}{|c|c|c|c|c|}
\hline \multirow[b]{2}{*}{ Strain } & \multirow[b]{2}{*}{$\begin{array}{l}\text { Addition of } \\
\text { erythromycin }\end{array}$} & \multicolumn{3}{|c|}{$\begin{array}{l}\text { Protease activity } \\
{\left[\mathrm{U}(\mathrm{ml} \text { supernatant })^{-1}\right]^{*}}\end{array}$} \\
\hline & & $12 \mathrm{~h}$ & $24 \mathrm{~h}$ & $48 \mathrm{~h}$ \\
\hline MT142 & - & $0 \cdot 18$ & 0.61 & 0.91 \\
\hline ME142 & - & 0.034 & 0.21 & 0.41 \\
\hline ME142 & + & 0.019 & 0.034 & 0.014 \\
\hline ME152 & - & 0.024 & 0.17 & $0 \cdot 31$ \\
\hline ME152 & + & 0.025 & 0.069 & 0.068 \\
\hline ME162 & - & 0.039 & 0.36 & 0.35 \\
\hline ME162 & + & 0.016 & 0.020 & 0.010 \\
\hline MI112 & - & 0.022 & 0.46 & 0.55 \\
\hline MT-2 & - & 0.057 & $0 \cdot 15$ & $0 \cdot 30$ \\
\hline
\end{tabular}

* Each strain was cultured in $2 \times \mathrm{SG}$ medium with or without erythromycin at $37^{\circ} \mathrm{C}$ for 12,24 or $48 \mathrm{~h}$. Viable cell numbers were $2 \times 10^{8}$ to $8 \times 10^{8}$ per ml of culture. Cell numbers of each Ery mutant cultured with and without erythromycin were similar. The culture supernatants were assayed as described in Methods.

Many spo0 mutants are incapable of developing competence, exceptions being spo0C, spo0G and spo0J mutants (Sadaie \& Kada, 1983). We therefore investigated the transformation capacity of ME142 using plasmid pUB1 10 (Table 4). ME142 showed poor competence (only $3 \%$ of the MT142 level), even under conditions when the cells were sporulation-proficient, i.e. without the addition of erythromycin.

\section{Development of an Eryr-associated protease-deficient mutant with normal competence}

The poor competence-development ability of ME142 would be a disadvantage for applications in which this strain was to be used as a host for molecular cloning. In order to isolate an Ery ${ }^{r}$ mutant with normal competence, chromosomal DNA from MI112, which exhibits normal competence, was introduced into ME142 by selecting for an unlinked $t r p^{+}$marker. An Ery mutant, ME152, was isolated which had recovered the normal frequency of pUB110-mediated transformation, but which retained a similar growth rate to that of ME142, and the conditional sporulation and protease deficiency characteristic of ME142 (Tables 2 and 3). These results indicate that the poor competence shown by ME142 is apparently independent of erythromycin resistance.

We have previously developed plasmids such as pTL12 (Tanaka \& Kawano, 1980), pNC601 and pNC602 (Kamakura et al., 1987) as cloning vectors carrying a Tmpr selection marker. Strains ME142, ME152 and MT142 were, however, resistant to trimethoprim ( $1 \mu \mathrm{g} \mathrm{ml}^{-1}$; Table 4) because of their thy $A$ thy $B^{+}$genetic background (Neuhard et al., 1978). In order to use these vectors in the Ery ${ }^{\mathrm{r}}$ mutants, we further constructed an $\mathrm{Ery}^{\mathrm{r}}$ strain carrying thy $A^{+}$thy $B^{+}$. By transforming ME152 DNA into competent cells of RM125, several Ery transformants were 
Table 4. Transformation frequency of MT142 and Ery ${ }^{r}$ mutants

\begin{tabular}{|c|c|c|c|c|}
\hline $\begin{array}{l}\text { Recipient } \\
\text { strain }\end{array}$ & $\begin{array}{l}\text { Selective } \\
\text { marker* }\end{array}$ & $\begin{array}{l}\text { No. of } \\
\text { viable cells } \mathrm{ml}^{-1}\end{array}$ & $\begin{array}{l}\text { No. of } \\
\text { transformants } \mathrm{ml}^{-1}\end{array}$ & $\begin{array}{l}\text { Transformation } \\
\text { frequency }\end{array}$ \\
\hline $\begin{array}{l}\text { MT142 } \\
\text { ME142 } \\
\text { ME152 } \\
\text { ME162 } \\
\text { MI112 }\end{array}$ & $\begin{array}{l}\mathbf{K} \mathbf{m}^{r} \\
\mathbf{K} \mathbf{m}^{r} \\
\mathbf{K} \mathbf{m}^{r} \\
\mathbf{K} \mathbf{m}^{r} \\
\mathbf{K} \mathbf{m}^{r}\end{array}$ & $\begin{array}{l}1.4 \times 10^{8} \\
1.7 \times 10^{8} \\
4.4 \times 10^{8} \\
6.6 \times 10^{7} \\
4.7 \times 10^{7}\end{array}$ & $\begin{array}{l}2.3 \times 10^{5} \\
6.5 \times 10^{3} \\
2.4 \times 10^{5} \\
7.4 \times 10^{4} \\
2.2 \times 10^{5}\end{array}$ & $\begin{array}{l}1.7 \times 10^{-3} \\
3.8 \times 10^{-5} \\
5.5 \times 10^{-4} \\
1.1 \times 10^{-3} \\
4.6 \times 10^{-3}\end{array}$ \\
\hline $\begin{array}{l}\text { MT142 } \\
\text { ME142 } \\
\text { ME152 } \\
\text { ME162 } \\
\text { MI112 }\end{array}$ & $\begin{array}{l}\text { Tmpr } \\
\text { Tmpr } \\
\text { Tmp } \\
\text { Tmp } \\
\text { Tmp }\end{array}$ & $\begin{array}{l}1.4 \times 10^{8} \\
1.7 \times 10^{8} \\
4.4 \times 10^{8} \\
6.6 \times 10^{7} \\
4.7 \times 10^{7}\end{array}$ & $\begin{aligned} \text { ND } \\
\text { ND } \\
\text { ND } \\
4.9 \times 10^{4} \dagger \\
5.9 \times 10^{4}\end{aligned}$ & $\begin{array}{c}- \\
- \\
- \\
7.4 \times 10^{-4} \dagger \\
1.3 \times 10^{-3}\end{array}$ \\
\hline
\end{tabular}

ND, not determined. MT142, ME142 and ME152 were Tmpr because of their thy A genotype (Neuhard et al., 1978).

* pUB110 and pNC601 DNA (0.23 and $\left.1 \cdot 1 \mu \mathrm{g} \mathrm{ml}^{-1}\right)$ were used to transform the cells to kanamycin resistance $\left(\mathrm{Km}^{\mathrm{r}}\right)$ and trimethoprim resistance $(\mathrm{Tmp} r)$, respectively.

† Tmp ${ }^{r}$ transformants of ME162 were selected on Spizizen agar supplemented with trimethoprim $\left(10 \mu \mathrm{g} \mathrm{ml}^{-1}\right)$.

obtained. One such transformant, ME162, was resistant to $1 \mu \mathrm{g}$ trimethoprim $\mathrm{ml}^{-1}$, but not to $10 \mu \mathrm{g} \mathrm{ml}^{-1}$. This strain showed normal competence for pNC601- and pUB110-mediated transformation (Table 4), and, like ME142 and ME152, was conditional for both the sporulation- and the protease-deficiency (Tables 2 and 3). This strain also showed a similar growth pattern to those of ME142 and ME152.

\section{Extracellular production of E. coli $\beta$-lactamase by B. subtilis ME162}

In order to test the usefulness of the protease-deficient phenotype of mutant ME162, we studied the secretion of the $E$. coli $\beta$-lactamase by this strain. A recombinant plasmid pNYB3 was constructed and used for the production of $\beta$-lactamase as described in Methods and Fig. 1 . The bla gene is transcribed from the promoter for the upstream $B$. subilis dfr operon consisting of genes thyB and dfrA (Iwakura et al., 1988; Nagami et al., 1988), and translated from the synthetic ribosome-binding site (Fig. 1c). The $\beta$-lactamase is secreted with the aid of the $\alpha$ amylase signal peptide. Since the $d f r$ promoter is a vegetative-type promoter (Iwakura et al., 1988), it functions in sporulation-deficient cells such as ME162.

ME162 and the wild-type strain, MI112, both carrying pNYB3, were grown in $2 \times$ SG medium containing antibiotics (trimethoprim) and erythromycin for ME162, or trimethoprim for MI112), and the $\beta$-lactamase activities in the culture supernatants and in the sonicated cells were measured after different periods of culture (Fig. 2). Both strains secreted more than $90 \%$ of $\beta$-lactamase into the culture supernatants, and their maximum activities were similar (about $8 \mathrm{U}$ $\mathrm{ml}^{-1}$ ) at the beginning of the stationary phase $(12 \mathrm{~h}) . \beta$-Lactamase activity in ME162 declined slightly during further culture, whereas that in MI112 declined drastically. At $24 \mathrm{~h}$, most of the activity in MI112 had disappeared, whereas in ME162 more than $70 \%$ of the maximum level remained. Under identical conditions, the host cells carrying the vector, pNC601, had no detectable $\beta$-lactamase activity. These results show that in $24 \mathrm{~h}$ cultures extracellular $\beta$ lactamase was about fivefold more stable in ME162 compared with that in MI112. The production of extracellular protease by MI112 increased throughout cultivation, whilst the levels produced by ME162 remained virtually unaltered; after $24 \mathrm{~h}$, MI112 secreted about 10 times as much protease as did ME162 (Fig. 2).

In order to determine the influence of extracellular protease on the stability of $\beta$-lactamase, equal volumes of the culture supernatants from $12 \mathrm{~h}$ and $20 \mathrm{~h}$ cultures were mixed, and the levels of $\beta$-lactamase activity were determined (Fig. 3). When the supernatants were obtained from MI112, the $\beta$-lactamase activity had decreased to about half the initial level after $0.5 \mathrm{~h}$, and had disappeared after $2 \mathrm{~h}$ of incubation. In contrast, the $\beta$-lactamase activity in the supernatants 

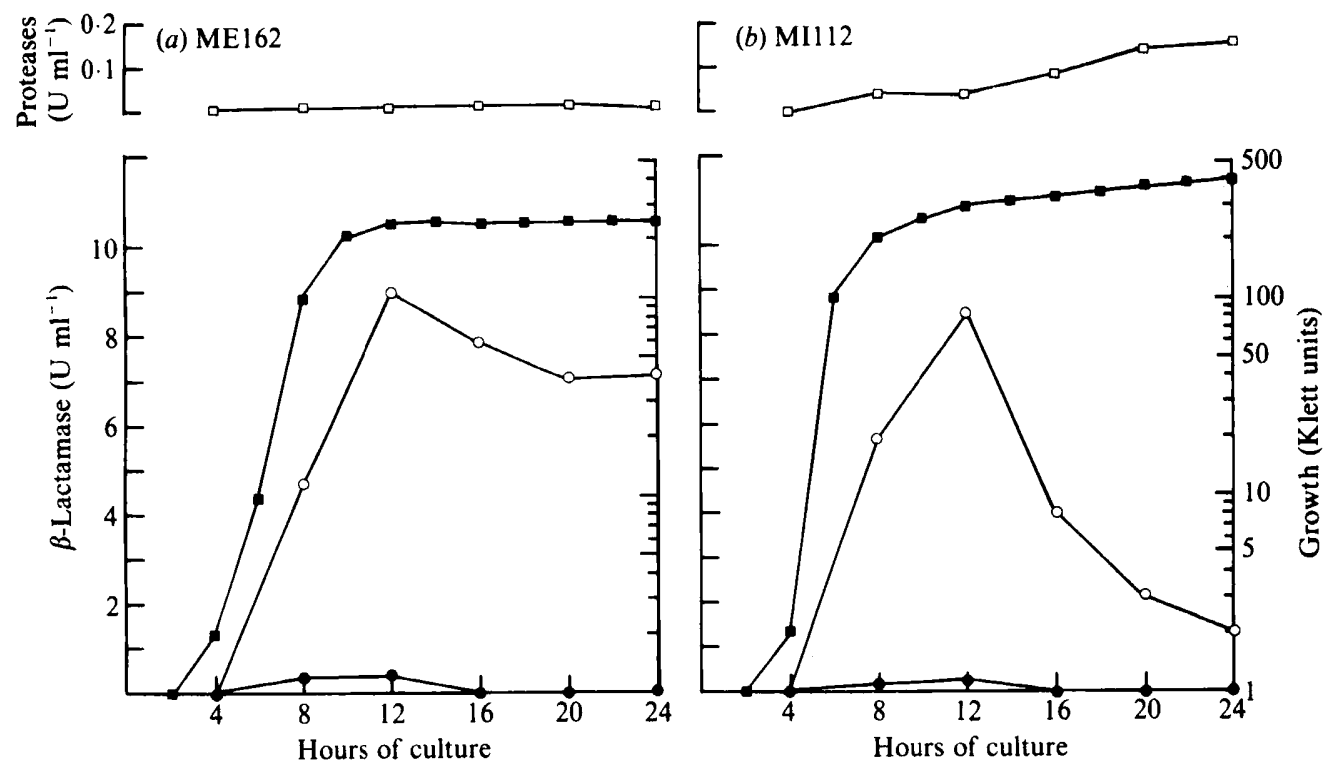

Fig. 2. Extracellular production of $E$. coli $\beta$-lactamase by $B$. subtilis ME162 (a) and MI112 (b), both carrying pNYB3. Cells were cultured at $37^{\circ} \mathrm{C}$ in $2 \times \mathrm{SG}$ medium $(0.5 \%$ inoculum) containing either trimethoprim and erythromycin for ME162 or trimethoprim for MI112. O, $\beta$-Lactamase activity in culture supernatants; $\beta$-lactamase activity in sonicated cells; $\square$, protease activity in the culture supernatants; $\boldsymbol{\square}$, growth monitored in a Klett-Summerson colorimeter.

obtained from ME162 declined at a slower rate, with approximately $75 \%$ of the initial level remaining after $3 \mathrm{~h}$ incubation. These results indicate that the proteolysis of $\beta$-lactamase in the supernatants of ME162 was greatly reduced as compared to that in the supernatants of the wildtype strain.

In spite of the protease deficiency in ME162, the amount of $\beta$-lactamase did not increase after $12 \mathrm{~h}$ as it did in a mutant with lesions in both the alkaline and neutral protease structural genes (Nakamura et al., 1985; Wong et al., 1986; Honjo et al., 1987). In order to understand the reasons for this difference in behaviour, we measured the intracellular $\beta$-galactosidase activity transcribed from the $d f r$ promoter in both ME162 and MI112 carrying pNZ2. Plasmid pNZ2 contains a fused gene consisting of the coding region of the $B$. subtilis prtR (amino acids 1-26) and the $E$. coli lacZ gene (amino acids 9-1023) downstream of the $d f r$ operon (Fig. $1 b$; Nagami \& Tanaka, 1986). Accordingly, the lac $Z$ gene is transcribed and translated by the same $d f r$ polycistronic expression system (Nagami et al., 1988) as in the case of $\beta$-lactamase production (Fig. 1). In this construct, the production of $\beta$-galactosidase reflects the activity of the $d f r$ polycistronic expression system, irrespective of the influence of extracellular proteases. As shown in Fig. 4 , the intracellular $\beta$-galactosidase activity in ME162 increased during exponential growth, reached a maximum in early stationary phase and remained at the same level during the stationary phase. Host cells carrying the vector, pNC61 (Nagami \& Tanaka, 1986 ), did not show $\beta$-galactosidase activity under the conditions that we used. This result shows that the synthesis of proteins driven by the $d f r$ promoter is lowered during stationary phase as compared to that in the exponential phase. The profile of $\beta$-galactosidase production was similar in MI112, although the maximum activity was only half that found in ME162 (Fig. 4). The reason for this difference is not known. Proteolytic degradation could not be ruled out as the reason for the limited secretion, since a small amount of protease activity was detectable in the culture supernatants of ME162 (Fig. 2, Table 3) and the $\beta$-lactamase activity in the mixture of supernatants in ME162 decreased gradually during incubation (Fig. 3). These results suggest that the limitation of $\beta$-lactamase secretion in ME162 is due to the combined effects of lowered synthesis and proteolytic degradation. 


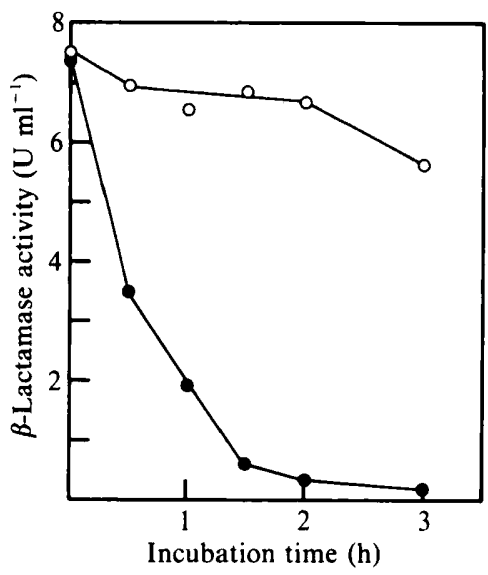

Fig. 3

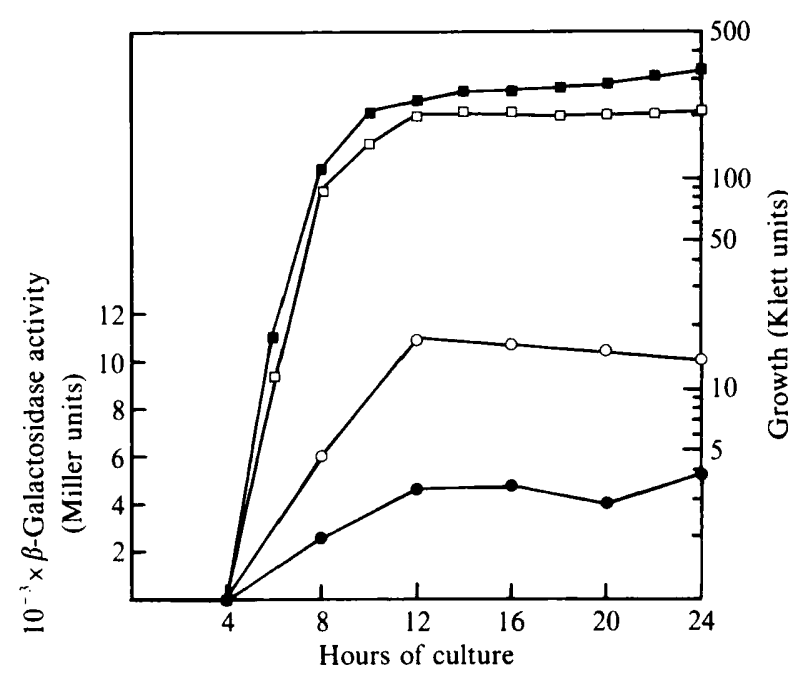

Fig. 4

Fig. 3. Stability of $\beta$-lactamase in culture supernatants. Equal volumes $(4 \mathrm{ml})$ of the $12 \mathrm{~h}$ and $20 \mathrm{~h}$ culture supernatants of each strain were mixed and incubated at $37^{\circ} \mathrm{C}$. $\beta$-Lactamase activities of the mixtures obtained from ME162 (O) and MI112(O) were assayed at the times indicated.

Fig. 4. Production of $E$. coli $\beta$-galactosidase by $B$. subtilis strains ME162 (O) and MI112 (O). $\beta$-Galactosidase activity was assayed as described in Methods. Growth of strains ME162 ( $\square$ ) and MI112 ( $\mathbf{a}$ ) was monitored in a Klett-Summerson colorimeter. Culture conditions were the same as those described in the legend to Fig. 2.

\section{DISCUSSION}

We have isolated a spontaneous Eryr mutant, B. subtilis ME142, which is conditional for sporulation, and produces only $2-10 \%$ of the wild-type level of extracellular proteases in the presence of erythromycin. The correlation between these conditional deficiencies suggests that the extracellular production of proteases is closely associated with the process of spore formation, although Yang et al. (1984) and Kawamura \& Doi (1984) reported that the extracellular proteases were not required for normal sporulation. The phenotype of ME142 is similar to that of a spo0A mutant (Sadaie \& Kada, 1983; Fahnestock \& Fischer, 1986) with respect to the extracellular-protease deficiency and lowered competence for transformation. However, we were able to isolate Eryr mutants, ME152 and ME162, with normal competence. Thus, these Ery ${ }^{\mathrm{r}}$ mutants are distinct from the spoOA mutant. Furthermore, these results indicate that ME142 carries two mutations, one responsible for the Ery ${ }^{\mathrm{r}}$ phenotype and the other conferring lowered competence for transformation.

Our aim was to investigate the possibility of utilizing this pleiotropic and conditional protease-deficient mutant as a host for the extracellular production of foreign proteins. A similar attempt was reported by Fahnestock \& Fischer (1986), in which a cloned staphylococcal protein A was produced by $B$. subtilis to a level of $1 \mathrm{~g}(1 \text { culture })^{-1}$ by use of a $\operatorname{spo} 0 A$ mutant showing a pleiotropic phenotype including protease deficiency. In the host-vector system described here, a sporulation-deficient host was used in combination with a vegetative-type promoter. The mutant was more effective in protecting $\beta$-lactamase from protease attack than was the wildtype (Fig. 2). The yield of $\beta$-lactamase by ME162 did not increase with cultivation time, probably because of the lowered synthesis of the enzyme from the $d f r$ promoter during stationary phase, and proteolytic degradation (Figs 3 and 4). However, the possibility of inefficient transport and/or processing of the $\beta$-lactamase precursor has not been eliminated. Recently, Schein et al. (1986) and Saunders et al. (1987) demonstrated that significant amounts of 
precursors of human interferon- $\alpha 2$ and human serum albumin were cell associated when the signal sequence and promoter of the $B$. amyloliquefaciens $\alpha$-amylase gene was joined to the coding sequence of the mature forms of these proteins.

Ruppen et al. (1986) succeeded in high-level intracellular expression of human growth hormone $\left(1.5 \mathrm{~g} \mathrm{l}^{-1}\right)$ by using a spo0 $A$ mutant of $B$. subtilis. Our experiment also demonstrated that the intracellular production of $\beta$-galactosidase in ME162 was twice that in MI112. More recently, Perego \& Hoch (1988) reported that the hpr gene product, a negative regulator of protease production, is constitutively overproduced in a spoOA mutant. It was also found that the hpr gene affects the production of the intracellular serine protease in addition to the extracellular proteases (Ruppen et al., 1988). These results may reflect the fact that there are lower activities of intracellular as well as extracellular proteases caused by the overexpression of the $h p r$ gene in sporulation-deficient strains such as $\operatorname{spoOA}$ and $\mathrm{Ery}^{\mathrm{r}}$ mutants. Therefore, it might be expected that sporulation-deficient strains in general may be suitable hosts for the intracellular production of foreign proteins by $\boldsymbol{B}$. subtilis.

We thank M. Kawata and M. Takahashi for technical assistance and Y. Teranishi for the support and interest in this work. We are grateful to I. Palva for the gift of the bla gene lacking its own signal sequence and S. Aiba for B. subtilis MT-2.

\section{REFERENCES}

Chang, S., Ho, D., Gray, O., Chang, S.-Y. \& Mclaughlin, J. (1983). Functional expression of human interferon genes and construction of a partition-proficient plasmid vector in B. subtilis. In Genetics of Industrial Microorganisms, pp. 227-231. Edited by Y. Ikeda \& T. Beppu. Tokyo: Kodansha.

Domoto, T., Kobayashi, K. \& Kobayashi, Y. (1975). Erythromycin resistant, conditional asporogenous mutant of Bacillus subtilis. In Spores VI, pp. 307-313. Edited by P. Gerhardt, R. N. Costilow \& H. L. Sadoff. Washington, DC: American Society for Microbiology.

FAHNESTOCK, S. R. \& FischeR, K. E. (1986). Expression of the staphylococcal protein A gene in Bacillus subtilis by gene fusions utilizing the promoter from Bacillus amyloliquefaciens $\alpha$-amylase gene. Journal of Bacteriology 165, 796-804.

FAHNESTOCK, S. R. \& FischeR, K. E. (1987). Proteasedeficient Bacillus subtilis host strains from production of staphylococcal protein A. Applied and Environmental Microbiology 53, 379-384.

FujII, M., Takagi, M., Imanaka, T. \& Aiba, S. (1983). Molecular cloning of a thermostable neutral protease gene from Bacillus stearothermophilus in a vector plasmid and its expression in Bacillus stearothermophilus and Bacillus subtilis. Journal of Bacteriology 154, 831-837.

Goldman, R. C. \& TiPPER, D. J. (1979). Morphology and patterns of protein synthesis during sporulation of Bacillus subtilis Ery' Spo(Ts) mutants. Journal of Bacteriology 138, 625-637.

Honjo, M., Akaoka, A., Nakayama, A., Shimada, H. \& Furutani, Y. (1985). Construction of the secretion vector containing the prepro-structure coding region of Bacillus amyloliquefaciens neutral protease gene and secretion of Bacillus subtilis $\alpha$-amylase and human interferon-beta in Bacillus subtilis. Journal of Biotechnology 2, 73-84.

Honjo, M., Nakayama, A., Io, A., Mita, I., KaWamURA, K., SAWAKURA, A. \& FURUTANI, Y. (1987).
Construction of a highly efficient host-vector system for secretion of heterologous protein in Bacillus subtilis. Journal of Biotechnology 6, 191-204.

Iwakura, M., Kawata, M., Tsuda, K. \& Tanaka, T. (1988). Nucleotide sequence of the thymidylate synthase $B$ and dihydrofolate reductase genes contained in one Bacillus subtilis operon. Gene 64, 9-20.

Kamakura, T., Kobayashi, K., Tanaka, T., YamaGUCHI, I. \& ENDO, T. (1987). Cloning and expression of a structural gene for blasticidin $\mathrm{S}$ deaminase, a nucleoside aminohydrolase. Agricultural and Biological Chemistry 51, 3165-3168.

KaWAmURA, F. \& DoI, R. H. (1984). Construction of a Bacillus subtilis double mutant deficient in extracellular alkaline and neutral proteases. Journal of Bacteriology 160, 442-444.

LEIGHTON, T. J. \& DoI, R. H. (1971). The stability of messenger ribonucleic acid during sporulation in Bacillus subtilis. Journal of Biological Chemistry 246, 3189-3195.

McKenzie, T., Hoshino, T., Tanaka, T. \& Sueoka, N. (1986). The nucleotide sequence of pUB110: some salient features in relation to replication and its regulation. Plasmid 15, 93-103.

NaGami, Y. \& TANAKA, T. (1986). Molecular cloning and nucleotide sequence of a DNA fragment from Bacillus natto that enhances production of extracellular proteases and levansucrease in Bacillus subtilis. Journal of Bacteriology 166, 20-28.

Nagami, Y., Kimura, M., Teranishi, Y.\& Tanaka, T. (1988). Construction of a new shuttle expression vector for Bacillus subtilis and Escherichia coli by using a polycistronic system. Gene 69, 59-69.

Nakamura, K., Furusato, T., Shiroza, T. \& YAMANE, K. (1985). Stable hyper-production of Escherichia coli $\beta$-lactamase by Bacillus subtilis grown on a $0.5 \mathrm{M}$ succinate-medium using a $B$. subtilis $\alpha$-amylase secretion vector. Biochemical and Biophysical $R e$ search Communications 128, 601-606.

Neuhard, J., Price, A. R., Shack, L. \& Thomassen, 
E. (1978). Two thymidylate synthetases in Bacillus subtilis. Proceedings of the National Academy of Sciences of the United States of America 75, 11941198.

Palva, I., Sarvas, M., Lehtovaara, P., Sibakov, M. \& KÄÄRIÄINEN, L. (1982). Secretion of Escherichia coli $\beta$-lactamase from Bacillus subtilis by the aid of $\alpha$ amylase signal sequence. Proceedings of the National Academy of Sciences of the United States of America 79, 5582-5586.

Palva, I., Lehtovaara, P., KäÄriäInen, L., Sibakov, M., Cantnel. K, K., Schein, C. H., Kashiwagi, K. \& Weissmann, C. (1983). Secretion of interferon by $B$. subtilis. Gene 22, 229-235.

Perego, M. \& Hoch, J. A. (1988). Sequence analysis and regulation of the $h p r$ locus, a regulatory gene for protease production and sporulation in Bacillus subtilis, Journal of Bacteriology 170, 2560-2567.

Piggot, P. J. \& CoOTE, J. G. (1976). Genetic aspects of bacterial endospore formation. Bacteriological Reviews 40, 908-962.

Ruppen, M., Band, L. \& Henner, D. J. (1986) Efficient expression of human growth hormone in Bacillus subtilis. In Bacillus Molecular Genetics and Biotechnology Applications, pp. 423-432. Edited by A. T. Ganesan \& J. A. Hoch. New York: Academic Press.

Ruppen, M. E., Alstine, G. L., Van \& Band, L. (1988). Control of intracellular serine protease expression in Bacillus subtilis. Journal of Bacteriology 170, 136-140.

SADAIE, Y. \& KadA, T. (1983). Formation of competent Bacillus subtilis cells. Journal of Bacteriology 153 , 813-821.

Sanders, C. W., Schmidt, B. J., Mallonee, R. L. \& GUYER, M. S. (1987). Secretion of human serum albumin from Bacillus subtilis. Journal of Bacteriology 169, 2917-2925.

Schein, C. H., Kashiwagi, K., Fujisawa, A. \& WeissmanN, C. (1986). Secretion of mature IFN- $\alpha 2$ and accumulation of uncleaved precursor by Bacillus subtilis transformed with a hybrid $\alpha$-amylase signal sequence-IFN- $\alpha 2$ gene. Bio/technology 4, 719-725.
Sharrock, R. A., Leighton, T. \& Wittmann, H. G. (1981). Macrolide and aminoglycoside antibiotic resistance mutations in the Bacillus subtilis ribosome resulting in temperature-sensitive sporulation. $\mathrm{Mol}$ ecular and General Genetics 183, 538-543.

Shiroza, T., Nakazawa, K., Tashiro, N., Yamane, K., Yanagi, K., Yamazaki, M., Tamura, G., Saito, H., KaWade, K. \& Taniguchi, T. (1985). Synthesis and secretion of biologically active mouse interferon$\beta$ using a Bacillus subtilis $\alpha$-amylase secretion vector. Gene 34, 1-8.

SPIZIZEN, J. (1958). Transformation of biochemically deficient strains of Bacillus subtilis by deoxyribonucleate. Proceedings of the National Academy of Sciences of the United States of America 44, 10721078.

Tanaka, T. \& Kawano, N. (1980). Cloning vehicles for the homologous Bacillus subtilis host-vector system. Gene 10, 131-136.

Tanaka, T., Kawata, M., Nagami, Y. \& Uchiyama, H. (1987). prtR enhances the mRNA level of the $B$. subtilis extracellular proteases. Journal of Bacteriology 169, 3044-3050.

Ulmanen, I., LUNDSTRÖM, K., LethovaARa, P., Sarvas, M., Ruohonen, M. \& Palva, I. (1985). Transcription and translation of foreign genes in Bacillus subtilis by the aid of a secretion vector. Journal of Bacteriology 162, 176-182.

Uozumi, T., Hoshino, T., Miwa, K., Horinouchi, S., BEPPU, T. \& ARIMA, K. (1977). Restriction and modification in Bacillus species. Genetic transformation of bacteria with DNA from different species, part 1. Molecular and General Genetics 152, 65-69.

WoNG, S.-L., KaWAmURa, F. \& DoI, R. H. (1986). Use of the Bacillus subtilis subtilisin signal peptide for efficient secretion of TEM $\beta$-lactamase during growth. Journal of Bacteriology 168, $1005-1009$.

Yang, M. Y., FerRari, E. \& Henner, D. J. (1984). Cloning of the neutral protease gene of Bacillus subtilis and the use of the cloned gene to create an in vitro-derived mutation. Journal of Bacteriology 160 , $15-21$. 